Randomized Trial

\title{
Fluoroscopic Cervical Interlaminar Epidural Injections in Managing Chronic Pain of Cervical Postsurgery Syndrome: Preliminary Results of a Randomized, Double-Blind, Active Control Trial
}

\footnotetext{
Laxmaiah Manchikanti, MD ${ }^{1,2}$, Yogesh Malla, MD1, Kimberly A. Cash, RT ${ }^{1}$,

Carla D. McManus, RN, BSN1', and Vidyasagar Pampati, MSc

From: ${ }^{\text {PPain }}$ Management Center of Paducah, Paducah, $\mathrm{KY}$; and

${ }^{2}$ University of Louisville Louisville, Kentucky

Dr. Manchikanti is Medical Director of the Pain Management Center of Paducah, Paducah, KY; and Associate Clinical Professor, Anesthesiology and Perioperative Medicine, University of Louisville, Louisville, KY.

Dr. Malla is an Interventional Pain Physician at the Pain Management Center of Paducah, Paducah, KY. Kimberly A. Cash is Research

Coordinator at the Pain Management Center of

Paducah, Paducah, KY

Carla D. McManus is Nursing Administrator at the Pain Management Center of Paducah, Paducah, KY. Vidyasagar Pampati is a Statistician at the Pain Management Center of Paducah, Paducah, KY.

Address correspondence: Laxmaiah Manchikanti, MD 2831 Lone Oak Road Paducah, Kentucky 42003 E-mail: drlm@thepainmd.

Disclaimer: There was no external funding in the preparation of this manuscript. Conflict of interest: None.

Manuscript received: $12 / 12 / 2011$ Accepted for publication: $12 / 28 / 2011$

Free full manuscript: www.painphysicianjournal.

Background: Cervical postsurgery syndrome is common with increasing cervical surgical interventions. Cervical spine surgery may fail in a certain proportion of patients with continued pain secondary to pseudoarthrosis, adjacent segment degeneration, inadequate decompression, iatrogenic instability, facet joint arthritis, deformity, and spinal stenosis. Among the various treatments available for managing cervical postsurgery syndrome, epidural steroid injections are one of the most common nonsurgical interventions. However there have not been any systematic evaluations regarding the effectiveness of cervical epidural injections in cervical postsurgery syndrome.

Study Design: A randomized, double-blind, active control trial.

Setting: A specialty referral, private interventional pain management practice in the United States.

Objectives: To evaluate the effectiveness of cervical interlaminar epidural injections of local anesthetic with or without steroids in providing effective and long-lasting relief in the management of chronic neck pain and upper extremity pain in patients with cervical postsurgery syndrome, and to evaluate the differences between local anesthetic with or without steroids.

Methods: Patients were randomly assigned to one of 2 groups: Group I patients received cervical interlaminar epidural injections of local anesthetic (lidocaine $0.5 \%, 5 \mathrm{~mL}$ ); Group II patients received cervical interlaminar epidural injections with $0.5 \%$ lidocaine, $4 \mathrm{~mL}$, mixed with $1 \mathrm{~mL}$ of nonparticulate betamethasone.

The study was designed to include 120 patients with 60 patients in each group. This analysis includes 56 patients. Randomization was performed by computer-generated, random allocation sequence by simple randomization.

Outcomes Assessment: Outcome measures included the Numeric Rating Scale (NRS), the Neck Disability Index (NDI), employment status, and opioid intake. Assessments at baseline and 3, 6, and 12 months posttreatment.

Significant pain relief was defined as $50 \%$ or more; significant improvement in NDI was defined as a reduction of $50 \%$ or more.

Results: Significant pain relief ( $\geq 50 \%$ ) was demonstrated in $71 \%$ of patients in Group I and $68 \%$ of patients in Group II. Functional status improvement was demonstrated by a reduction (> 50\%) in the NDI scores in $71 \%$ of Group I and $64 \%$ of Group II at 12 months. The overall average procedures per year were $4.0 \pm 0.7$ in Group I and $4.1 \pm 1.0$ in Group Il; the average total relief per year was $39.6 \pm 11.8$ weeks in Group I and $41.2 \pm 15.8$ weeks in Group II over the 52 week study period in the patients defined as successful. In the successful group, the combined pain relief and neck disability improvement was seen in $87 \%$ in Group I and $72 \%$ of the patients in Group II.

Limitations: The study results are limited by the lack of a placebo group and a preliminary report of 56 patients, 28 in each group.

Conclusion: Cervical interlaminar epidural injections with local anesthetic with or without steroids were effective in $67 \%$ of patients overall and $87 \%$ in Group I and $72 \%$ in Group II, in successful group patients with chronic function-limiting neck pain and upper extremity pain secondary to cervical postsurgery syndrome.

Key words: Chronic neck pain, upper extremity pain, cervical disc herniation, cervical spinal stenosis, cervical postsurgery syndrome, cervical epidural injections, epidural steroids, local anesthetics.

CLINICAL TRIAL: NCT01071369

Pain Physician 2012; 15:13-26
} 
hronic persistent neck pain is common in the adult general population, with an explosion Jof diagnostic and therapeutic measures resulting in a health care crisis (1-23). Cervical spine surgery within the United States has risen dramatically over the past 2 decades $(22,23)$, with a 10-fold geographic variation (24). Cervical spine fusions are the most common surgical interventions for degenerative cervical spine disease $(15,22-26)$. Optimistic estimations of fusion for neck pain in the literature are approximately $70 \%$ favorable results (22). Thus, cervical spine surgery may fail in a certain proportion of patients secondary to pseudoarthrosis, epidural fibrosis, adjacent segment degeneration, inadequate decompression, iatrogenic instability, facet joint arthritis, spinal stenosis, and deformity (22). In an analysis of preoperation after surgical treatment of degenerative cervical spine disorders in 900 cases (25), the authors evaluated 5 different operative techniques. They showed an overall revision rate of $13.4 \%$, as high as $32 \%$ for posterior instrumentation, and $42 \%$ pseudoarthrosis rates for cervical discectomy and fusion over 3 or more levels (22,25-28).

Cervical postsurgery syndrome represents a cluster of symptoms following cervical spine surgery wherein the expectations of the patient and spine surgeon are not met. Animal models of postlumbar laminectomy syndrome demonstrated paraspinal muscle spasms, tail contractures, pain behaviors, tactile allodynia, epidural and perineural scarring, and nerve root adherence to the underlying disc and pedicle (29-33). It also has been postulated that there may be a final common pathway with all the described etiologies, which results in peripheral and central facilitation potentiated by inflammatory and nerve injury mechanisms (31-33).

Cervical epidural injections (interlaminar or transforaminal) have been used to treat chronic neck and radicular pain from herniated discs, spinal stenosis, pain of discogenic origin, and cervical postsurgery syndrome (1). However, the evidence for cervical interlaminar epidural injections has been a subject of debate and at best is only moderately successful in managing cervical radiculopathy. There have not been any significant evaluations for cervical postsurgery syndrome, only the sporadic inclusion of patients in evaluating the effectiveness of cervical epidural injections(1,34-36). Recent studies utilizing fluoroscopic cervical interlaminar epidural injections for cervical disc herniation or axial pain have illustrated promising results, especially in patients who are judged to be successful in practical controlled, randomized, double-blind trials $(37,38)$.

The underlying mechanism of epidurally administered local anesthetic and steroids is not clear. It has been hypothesized that the effects of a neural blockade are dependent on the anti-inflammatory properties of corticosteroids (39-45). However, there is also emerging evidence that local anesthetics may be equally effective as steroids in managing various types of spinal pain with multiple interventions $(1,8,37,38,42,46-59)$.

Cervical epidural injections have not been performed utilizing contemporary interventional pain management techniques with fluoroscopy and targeted delivery of medication in cervical postsurgery syndrome. Consequently, this study is undertaken to evaluate the role of cervical interlaminar epidural injections in patients with chronic, function-limiting, neck pain and upper extremity pain secondary to cervical postsurgery syndrome using local anesthetic with or without steroids. The study is designed to evaluate 120 patients. This preliminary report includes 56 patients completing a one-year follow-up.

\section{Methods}

The study is being conducted in a private interventional pain management practice and specialty referral center in the United States. It is being performed based on Consolidated Standards of Reporting Trials (CONSORT) guidelines (60). The study protocol was approved by the Institutional Review Board (IRB) and registered with the U.S. Clinical Trial Registry.

\section{Participants}

New patients presenting for interventional pain management were recruited as study participants.

\section{Interventions}

All patients were provided with the IRB-approved protocol and informed consent which described in detail all aspects of the study and withdrawal process.

Patients were assigned to one of 2 groups: Group I patients received cervical interlaminar epidural injections of local anesthetic (lidocaine $0.5 \%, 5 \mathrm{~mL}$ ); Group Il patients received cervical interlaminar epidural injections with $0.5 \%$ lidocaine, $4 \mathrm{~mL}$, mixed with $1 \mathrm{~mL}(6 \mathrm{mg})$ of nonparticulate betamethasone for a total of $5 \mathrm{~mL}$ of injectate. 


\section{Pre-Enrollment Evaluation}

The pre-enrollment evaluation included demographic data, medical and surgical history with coexisting disease(s), radiologic investigations, physical examination, pain rating scores using the Numeric Rating Scale (NRS), work status, opioid intake, and functional status assessment using the Neck Disability Index (NDI).

\section{Inclusion Criteria}

Inclusion criteria were patients with cervical postsurgery syndrome with surgery performed at least one year before enrollment; patients who were 18 years of age; patients with a history of chronic function-limiting neck and upper extremity pain of at least 6 months duration one year after surgery; and patients who were competent to understand the study protocol and provide voluntary, written informed consent and participate in outcome measurements.

Exclusion criteria were those without previous cervical spine surgery; uncontrollable or unstable opioid use; uncontrolled psychiatric disorders; uncontrolled medical illness either acute or chronic; any conditions that could interfere with the interpretation of the outcome assessments; pregnant or lactating women; and patients with a history or potential for adverse reaction(s) to local anesthetics or steroid.

\section{Description of Interventions}

All cervical interlaminar epidural procedures were performed by one physician in an ambulatory surgery setting, in a sterile operating room, under fluoroscopy, with patients in the prone position, under appropriate monitoring with intravenous access and sedation with midazolam and fentanyl. Access to the epidural space was obtained under sterile conditions with the loss of resistance technique under fluoroscopic visualization. The epidural space was entered between $\mathrm{C} 7$ and $\mathrm{T} 1$ to C5 and C6 with confirmation by injection of nonionic contrast medium, but always below the scar from posterior surgical interventions. Following this, an injection of $5 \mathrm{~mL}$ of preservative-free lidocaine hydrochloride $0.5 \%$ or $4 \mathrm{~mL}$ of preservative-free lidocaine mixed with $6 \mathrm{mg}$ of nonparticulate betamethasone was carried out.

Repeat cervical epidural injections were provided based on the response to prior cervical epidural injections, determined by improvement in physical and functional status. Further, repeat cervical epidural injections were performed only when increased levels of pain were reported with deteriorating relief below $50 \%$.

\section{Additional Interventions}

All patients underwent the treatments as assigned. A patient was unblinded on request or if an emergency situation arose. Patients who were nonresponsive continued with conservative management and were followed without further epidural injections unless they requested unblinding.

\section{Co-Interventions}

Most patients were receiving opioids, nonopioid analgesics, and adjuvant analgesics; some were involved in a therapeutic exercise program. If patients were improving significantly and the medical necessity for these drugs was lacking, medications were stopped or dosages were decreased. In addition, some dosages were increased, based on medical necessity. All patients continued previously directed exercise programs, as well as their work. Thus, in this study, there was no specific physical therapy, occupational therapy, bracing, or other interventions offered other than the study intervention.

\section{Objectives}

The study was designed to evaluate the effectiveness of cervical interlaminar epidural injections with or without steroids in managing chronic neck and upper extremity pain secondary to cervical postsurgery syndrome in providing effective and long-lasting pain relief and to evaluate the differences between local anesthetic with or without steroids.

\section{Outcomes}

Outcomes measured included NRS, NDI, work status, and opioid intake in terms of morphine equivalents. Assessments were done at baseline, 3, 6, and 12 months posttreatment.

Significant improvement was defined as at least $50 \%$ pain relief associated with $50 \%$ improvement in NDI. The NRS and NDI have been shown to be valid and reliable in patients with mechanical neck pain (61-63).

Opioid intake was evaluated based on the dosage frequency and schedule of the drug, with conversion to morphine equivalents (64).

Patients unemployed or employed on a part-time basis with limited or no employment due to pain were classified as employable. Patients who chose not to work, were retired, or were homemakers (not working, but not due to pain) were not considered to be in the employment pool. 


\section{Sample Size}

The sample size was calculated based on significant pain relief. Considering a 0.052 -sided significance level, a power of $80 \%$, and an allocation ratio of $1: 1,55$ patients in each group were estimated (65). Allowing for a $10 \%$ attrition/ noncompliance rate, 60 patients were required.

Previous studies of interventional techniques identified 50 to 60 patients or even smaller numbers as appropriate $(29,30,49-59,66-68)$.

\section{Randomization}

From a total of 120 patients, 60 patients will be randomly assigned into each group.

\section{Sequence Generation}

Randomization was performed by computergenerated random allocations sequence by simple randomization.

\section{Allocation Concealment}

The operating room nurse assisting with the procedure randomized the patients and prepared the drugs appropriately.

\section{Implementation}

Participants were invited to enroll in the study if they met inclusion criteria. One of the 3 nurses assigned as coordinators of the study enrolled the participants and assigned participants to their respective groups.

\section{Blinding (Masking)}

Participants and those administering the interventions were blinded to the group assignments. Both solutions were clear; it was impossible to identify if the steroid had been added or not. Further, blinding was ensured by mixing the patients with other patients receiving routine treatment and by not informing the physician performing the procedures which patients were in the study. All one-year follow-up patients were selected by a statistician not involved in patient care. The unblinding results were not disclosed to either the treating physician, other participants, or patients not enrolled in the study. Thus, the nature of blinding was not interrupted.

\section{Statistical Methods}

Statistical analyses included the chi-squared statistic, Fisher's exact test, $t$ test, and paired t test. Results were considered statistically significant if the $P$ value was less than 0.05 .
Chi-squared statistic was used to test the differences in proportions. Fisher's exact test was used wherever the expected value was less than 5; a paired t test was used to compare the pre- and posttreatment results of average pain scores and NDI measurements at baseline versus 3, 6, and 12 months. For comparison of mean scores between groups, t test was performed.

\section{Intent-to-Treat-Analysis}

An intent-to-treat-analysis was performed. Either the last follow-up data or initial data were utilized in patients who dropped out of the study and no other data were available. Sensitivity analysis was performed utilizing best case, worse case, and last follow-up data.

\section{Results}

\section{Participant Flow}

Figure 1 illustrates the participant flow.

\section{Recruitment}

The recruitment period was started in February 2008 and is ongoing.

\section{Baseline Data}

Baseline demographic and clinical characteristics of each group are illustrated in Table 1. There were no significant differences noted except for gender. Of the 56 patients included in the study, anterior surgery was performed in 49 or $88 \%$ of the patients, posterior surgery in 5 or $9 \%$ of the patients, and both anterior and posterior surgery in 4 or $7 \%$ of the patients.

\section{Analysis of Data}

\section{Numbers Analyzed}

A schematic illustration of patient flow is provided in Fig. 1. Fifty-six patients completed the one-year follow-up; 28 patients in each group. The data were available in the majority of the included patients. An intent-to-treat analysis was performed due to unavailable data at 12 months for 4 patients in Group I and for 2 patients in Group II.

\section{Sensitivity Analysis}

A sensitivity analysis with changes in the numeric pain scores was performed utilizing the last follow-up score, best case scenario, and worst case scenario. There were no significant differences; therefore, the intentto-treat analysis with last follow-up visit was used. 


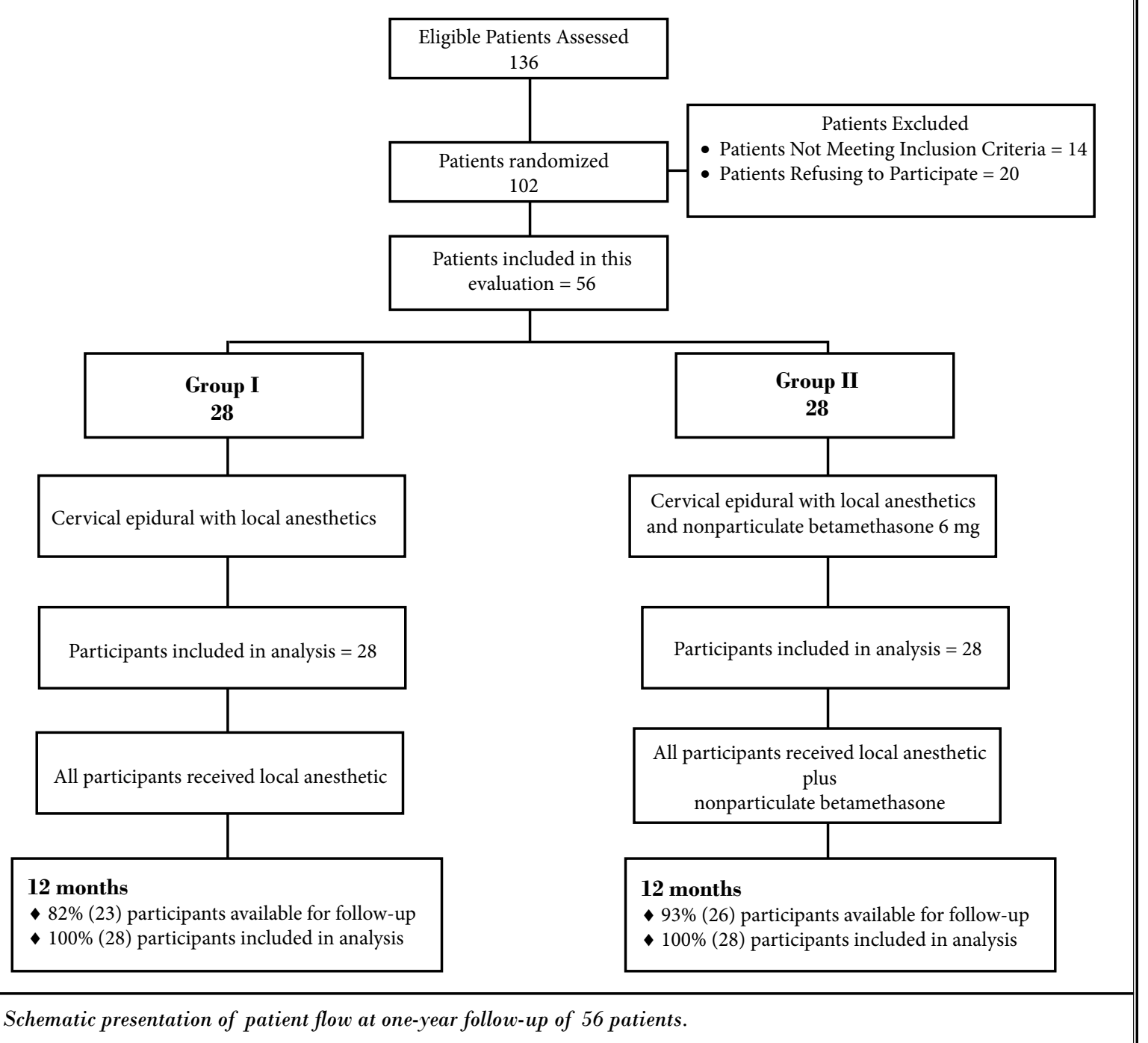

\section{Outcomes}

\section{Pain Relief}

Table 2 illustrates the NRS scores. Pain scores changed significantly from baseline at 3, 6, and 12 months in both groups.

\section{Functional Assessment}

Functional assessment results assessed by the NDI are illustrated in Table 3.

\section{Employment Characteristics}

Table 4 demonstrates employment characteristics in both groups.

\section{Opioid Intake}

Table 5 illustrates the daily opioid intake between the groups at baseline, at 3 months, at 6 months, and at 12 months, with no significant changes.

\section{Therapeutic Procedural Characteristics}

Therapeutic procedural characteristics are illustrated in Table 6. Epidural entry was performed between $\mathrm{C} 7$ and $\mathrm{T} 1$ in $32 \%$ of the patients, between $\mathrm{C} 6$ and $\mathrm{C} 7$ in $57 \%$ of the patients, and between $\mathrm{C} 5$ and $\mathrm{C} 6$ in $11 \%$ of the patients.

Average pain relief per year showed no significant differences: $33.2+17.4$ weeks in Group I and $37.8 \pm$ 18.2 weeks in Group II. The average number of injec- 
Table 1. Baseline demographic characteristics.

\begin{tabular}{|c|c|c|c|c|}
\hline & & $\begin{array}{c}\text { Group } 1 \\
(28)\end{array}$ & $\begin{array}{c}\text { Group II } \\
(28)\end{array}$ & $P$ value \\
\hline \multirow{2}{*}{ Sex } & Male & $36 \%$ & $68 \%$ & \multirow{2}{*}{0.016} \\
\hline & Female & $64 \%$ & $32 \%$ & \\
\hline Age & Mean \pm standard deviation $(\mathrm{SD})$ & $48.3+9.9$ & $49.0+10.3$ & 0.782 \\
\hline Weight & Mean \pm SD & $200.0 \pm 50.6$ & $179.2 \pm 39.9$ & 0.093 \\
\hline Height & Mean \pm SD & $65.6 \pm 4.2$ & $68.2 \pm 5.0$ & 0.03 \\
\hline Duration of Pain (months) & Mean \pm SD & $122.3 \pm 77.7$ & $111.2 \pm 73.9$ & 0.585 \\
\hline \multirow{2}{*}{ Onset of Pain } & Gradual & $50 \%$ & $36 \%$ & \multirow{2}{*}{0.280} \\
\hline & Injury & $50 \%$ & $64 \%$ & \\
\hline \multirow{4}{*}{ Neck Pain Distribution } & Neck pain only & $14 \%$ & $14 \%$ & \multirow{4}{*}{0.993} \\
\hline & $\begin{array}{l}\text { Neck pain worse than upper } \\
\text { extremity }\end{array}$ & $50 \%$ & $53 \%$ & \\
\hline & $\begin{array}{l}\text { Upper extremity worse than neck } \\
\text { pain }\end{array}$ & $4 \%$ & $4 \%$ & \\
\hline & Both equal & $32 \%$ & $29 \%$ & \\
\hline \multirow{3}{*}{ Surgical Interventions } & Anterior surgery & $86 \%(24)$ & $89 \%(25)$ & 1.000 \\
\hline & Posterior surgery & $14 \%(4)$ & $4 \%(1)$ & 0.352 \\
\hline & Anterior and posterior surgery & $7 \%(2)$ & $7 \%(2)$ & 0.570 \\
\hline \multirow{3}{*}{ Number of Surgeries } & One & $86 \%(24)$ & $79 \%(22)$ & \multirow{3}{*}{0.485} \\
\hline & Two & $11 \%(3)$ & $18 \%(5)$ & \\
\hline & $>$ Two & $3 \%(1)$ & $3 \%(1)$ & \\
\hline Numeric Rating Score & Mean \pm SD & $8.0 \pm 1.23$ & $7.8 \pm 0.9$ & 0.534 \\
\hline Neck Disability Index & Mean \pm SD & $30.0 \pm 5.0$ & $28.8 \pm 4.0$ & 0.289 \\
\hline
\end{tabular}

Table 2. Mean pain relief of NRS scores and proportion of patients with significant pain relief $(\geq 50 \%)$.

\begin{tabular}{|l|c|c|c|}
\hline $\begin{array}{c}\text { Numeric } \\
\text { Rating } \\
\text { Score }\end{array}$ & Group I (28) & Group II (28) & \multirow{2}{*}{ P value } \\
\cline { 2 - 3 } & Mean \pm SD & Mean \pm SD & \\
\hline Baseline & $8.0 \pm 1.23$ & $7.8 \pm 0.9$ & 0.534 \\
\hline 3 months & $\begin{array}{c}3.7^{*} \pm 1.2 \\
(79 \%)\end{array}$ & $\begin{array}{c}4.0^{*} \pm 1.2 \\
(71 \%)\end{array}$ & 0.369 \\
\hline 6 months & $\begin{array}{c}3.7^{*} \pm 1.1 \\
(71 \%)\end{array}$ & $\begin{array}{c}3.8^{*} \pm 1.1 \\
(75 \%)\end{array}$ & 0.714 \\
\hline 12 months & $\begin{array}{c}3.6^{*} \pm 1.1 \\
(71 \%)\end{array}$ & $\begin{array}{c}3.9^{*} \pm 1.4 \\
(68 \%)\end{array}$ & 0.465 \\
\hline
\end{tabular}

Percentages in parentheses indicate proportion of participants with significant relief ( $\geq 50 \%$ reduction in Numeric Rating Score from baseline)

${ }^{*}$ indicates significant difference with baseline values $(P<0.001)$
Table 3. Functional assessment evaluated by Neck Disability Index with mean improvement and proportion of patients with significant improvement.

\begin{tabular}{|l|c|c|c|}
\hline $\begin{array}{c}\text { Neck } \\
\text { Disability } \\
\text { Index }\end{array}$ & $\begin{array}{c}\text { Group I } \\
(\mathbf{2 8})\end{array}$ & $\begin{array}{c}\text { Group II } \\
(\mathbf{2 8})\end{array}$ & P value \\
\hline Baseline & Mean \pm SD & Mean \pm SD & \\
\hline 3 months & $\begin{array}{c}15.9^{*} \pm 5.3 \\
(71 \%)\end{array}$ & $\begin{array}{c}14.8^{*} \pm 5.7 \\
(75 \%)\end{array}$ & 0.451 \\
\hline 6 months & $\begin{array}{c}15.3^{*} \pm 5.0 \\
(68 \%)\end{array}$ & $\begin{array}{c}14.6^{*} \pm 5.8 \\
(75 \%)\end{array}$ & 0.656 \\
\hline 12 months & $\begin{array}{c}15.0^{*} \pm 4.7 \\
(71 \%)\end{array}$ & $\begin{array}{c}15.0^{*} \pm 5.6 \\
(64 \%)\end{array}$ & 0.9980 \\
\hline
\end{tabular}

Percentages in parenthesis indicate proportion of patients with significant improvement with NDI scores from baseline $(\geq 50 \%)$.

${ }^{*}$ indicates significant difference with baseline values $(P<0.001)$ 
tions per year was $3.7 \pm 0.9$ in Group I and $4.0 \pm 1.1$ in Group II. However, when patients were separated into successful and failed groups, the average number of in-

Table 4. Employment characteristics.

\begin{tabular}{|l|c|c|c|c||}
\hline \multirow{2}{*}{\begin{tabular}{l} 
Employment \\
\cline { 2 - 5 }
\end{tabular}} & \multicolumn{2}{|c|}{ Group I } & \multicolumn{2}{c|}{ Group II } \\
\cline { 2 - 5 } & Baseline & $\begin{array}{c}\mathbf{1 2} \\
\text { months }\end{array}$ & Baseline & $\begin{array}{c}\mathbf{1 2} \\
\text { months }\end{array}$ \\
\hline $\begin{array}{l}\text { Employed } \\
\text { Part-time }\end{array}$ & 2 & 2 & 1 & 0 \\
\hline $\begin{array}{l}\text { Employed } \\
\text { Full-time }\end{array}$ & 2 & 2 & 6 & 8 \\
\hline $\begin{array}{l}\text { Unemployed } \\
\text { (Due to Pain) }\end{array}$ & 2 & 2 & 2 & 1 \\
\hline Not Working & 0 & 0 & 0 & 0 \\
\hline $\begin{array}{l}\text { Eligible for } \\
\text { Employment }\end{array}$ & 6 & 6 & 9 & 9 \\
\hline Total Employed & 4 & 4 & 7 & 8 \\
\hline Housewife & 18 & 18 & 16 & 16 \\
\hline Disabled & 3 & 13 & 2 & 2 \\
\hline Retired & 1 & 1 & 1 & 1 \\
\hline $\begin{array}{l}\text { Total Number of } \\
\text { Patients }\end{array}$ & 28 & 28 & 28 & 28 \\
\hline \hline
\end{tabular}

jections per year was $4.0 \pm 0.7$ in Group I and $4.1 \pm 1.0$ in Group II in the successful group, and $2.4 \pm 0.6$ for Group I and $2.7 \pm 0.6$ for Group II in the failed group. Total relief of $39.6 \pm 11.8$ weeks was obtained in the successful group in Group I; in Group II it was $41.2 \pm 15.8$ weeks. In contrast, the total relief was $4.4 \pm 1.7$ weeks in Group I and $9.0 \pm 9.6$ weeks in Group II for the failed groups.

The initial therapy was considered to be successful if a patient obtained consistent relief lasting at least 3 weeks with 2 initial injections. All others were considered failures.

Combined significant pain relief and functional status improvement are illustrated in Fig.2.

Table 5. Daily opioid intake (morphine equivalence mg).

\begin{tabular}{|l|c|c|c||}
\hline $\begin{array}{c}\text { Opioid Intake } \\
\text { (Morphine } \\
\begin{array}{c}\text { Equivalence in } \\
\text { mg) }\end{array}\end{array}$ & Group I (28) & $\begin{array}{c}\text { Group II } \\
\mathbf{( 2 8 )}\end{array}$ & \multirow{2}{*}{$\begin{array}{c}\text { P } \\
\text { value }\end{array}$} \\
\cline { 2 - 3 } & Mean \pm SD & Mean \pm SD & \\
\hline Baseline & $52.21 \pm 42.34$ & $90.32 \pm 104.54$ & 0.079 \\
\hline 3 months & $44.68 \pm 42.91$ & $64.25 \pm 56.01$ & 0.148 \\
\hline 6 months & $44.68 \pm 42.91$ & $63.54 \pm 56.20$ & 0.164 \\
\hline 12 months & $53.74 \pm 51.00$ & $63.54 \pm 56.20$ & 0.502 \\
\hline
\end{tabular}

Table 6. Therapeutic procedural characteristics with procedural frequency, average relief per procedure, and average total relief in weeks over a period of one year.

\begin{tabular}{|c|c|c|c|c|c|c|}
\hline & \multicolumn{2}{|c|}{ Successful Patients } & \multicolumn{2}{|c|}{ Failed Patients } & \multicolumn{2}{|c|}{ Combined } \\
\hline & $\begin{array}{c}\text { Group I } \\
(\mathbf{2 3})\end{array}$ & $\begin{array}{c}\text { Group II } \\
\text { (25) }\end{array}$ & $\begin{array}{c}\text { Group I } \\
\text { (5) }\end{array}$ & $\begin{array}{c}\text { Group II } \\
\text { (3) }\end{array}$ & $\begin{array}{c}\text { Group I } \\
\text { (28) }\end{array}$ & $\begin{array}{c}\text { Group II } \\
\text { (28) }\end{array}$ \\
\hline 1st Procedure Relief & $\begin{array}{c}5.2 \pm 3.4 \\
(24)\end{array}$ & $\begin{array}{c}4.8 \pm 4.1 \\
\quad(25)\end{array}$ & $\begin{array}{c}1.9 \pm 1.6 \\
(5)\end{array}$ & $\begin{array}{l}1.4 \pm 1.0 \\
\text { (3) }\end{array}$ & $\begin{array}{c}4.6 \pm 3.4 \\
(28)\end{array}$ & $\begin{array}{c}4.5 \pm 4.1 \\
(28)\end{array}$ \\
\hline 2nd Procedure Relief & $\begin{array}{c}8.8 \pm 3.7 \\
(23)\end{array}$ & $\begin{array}{c}7.8 \pm 4.6 \\
(25)\end{array}$ & $\begin{array}{c}2.0 \pm 2.1 \\
(5)\end{array}$ & $\begin{array}{c}1.3 \pm 1.5 \\
\text { (3) }\end{array}$ & $\begin{array}{c}7.6 \pm 4.3 \\
(28)\end{array}$ & $\begin{array}{c}7.1 \pm 4.8 \\
\quad(28)\end{array}$ \\
\hline 3rd Procedure Relief & $\begin{array}{c}12.4 \pm 5.1 \\
\quad(22)\end{array}$ & $\begin{array}{c}14.9 \pm 12.0 \\
(23)\end{array}$ & $\begin{array}{c}1.5 \pm 2.1 \\
(2)\end{array}$ & $\begin{array}{c}9.5 \pm 12.0 \\
\text { (2) }\end{array}$ & $\begin{array}{c}11.5 \pm 5.8 \\
(24)\end{array}$ & $\begin{array}{c}14.5 \pm 11.9 \\
(25)\end{array}$ \\
\hline 4th Procedure Relief & $\begin{array}{c}13.2 \pm 3.3 \\
(20)\end{array}$ & $\begin{array}{l}12.1 \pm 1.9 \\
\quad(19)\end{array}$ & - & - & $\begin{array}{c}13.2 \pm 3.3 \\
\quad(20)\end{array}$ & $\begin{array}{c}12.1 \pm 1.9 \\
(19)\end{array}$ \\
\hline 5th Procedure Relief & $\begin{array}{c}12.5 \pm 1 \\
(4)\end{array}$ & $\begin{array}{c}13.0 \pm 6.1 \\
(10)\end{array}$ & - & - & $\begin{array}{c}12.5 \pm 1 \\
\quad(4)\end{array}$ & $\begin{array}{c}13.0 \pm 6.1 \\
(10)\end{array}$ \\
\hline Number of Procedures per Year & $\begin{array}{c}4.0 \pm 0.7 \\
(23)\end{array}$ & $\begin{array}{c}4.1 \pm 1.0 \\
(25)\end{array}$ & $\begin{array}{c}2.4 \pm 0.6 \\
(5)\end{array}$ & $\begin{array}{c}2.7 \pm 0.6 \\
\text { (3) }\end{array}$ & $\begin{array}{c}3.7 \pm 0.9 \\
(28)\end{array}$ & $\begin{array}{c}4.0 \pm 1.1 \\
(28)\end{array}$ \\
\hline Average Relief per Procedure & $\begin{array}{c}9.8 \pm 12.8 \\
(23)\end{array}$ & $\begin{array}{c}10.2 \pm 4.6 \\
(25)\end{array}$ & $\begin{array}{c}1.9 \pm 0.6 \\
(5)\end{array}$ & $\begin{array}{c}3.3 \pm 3.1 \\
(3)\end{array}$ & $\begin{array}{c}8.4 \pm 3.8 \\
(28)\end{array}$ & $\begin{array}{c}9.4 \pm 4.9 \\
(28)\end{array}$ \\
\hline Average Relief per Procedure 3rd Procedure and After & $\begin{array}{c}12.8 \pm 3.1 \\
(22)\end{array}$ & $\begin{array}{c}15.3 \pm 11.9 \\
(23)\end{array}$ & $\begin{array}{c}1.4 \pm 1.9 \\
(2)\end{array}$ & $\begin{array}{c}9.4 \pm 12.2 \\
(2)\end{array}$ & $\begin{array}{c}11.8 \pm 4.4 \\
\quad(24)\end{array}$ & $\begin{array}{c}14.8 \pm 11.8 \\
(25)\end{array}$ \\
\hline Total Relief per Year (weeks) & $\begin{array}{c}39.6 \pm 11.8 \\
(23)\end{array}$ & $\begin{array}{c}41.2 \pm 15.8 \\
(25)\end{array}$ & $\begin{array}{c}4.4 \pm 1.7 \\
(5)\end{array}$ & $\begin{array}{c}9.0 \pm 9.6 \\
\text { (3) }\end{array}$ & $\begin{array}{c}33.2 \pm 17.4 \\
\quad(28)\end{array}$ & $\begin{array}{c}37.8 \pm 18.2 \\
(28)\end{array}$ \\
\hline
\end{tabular}




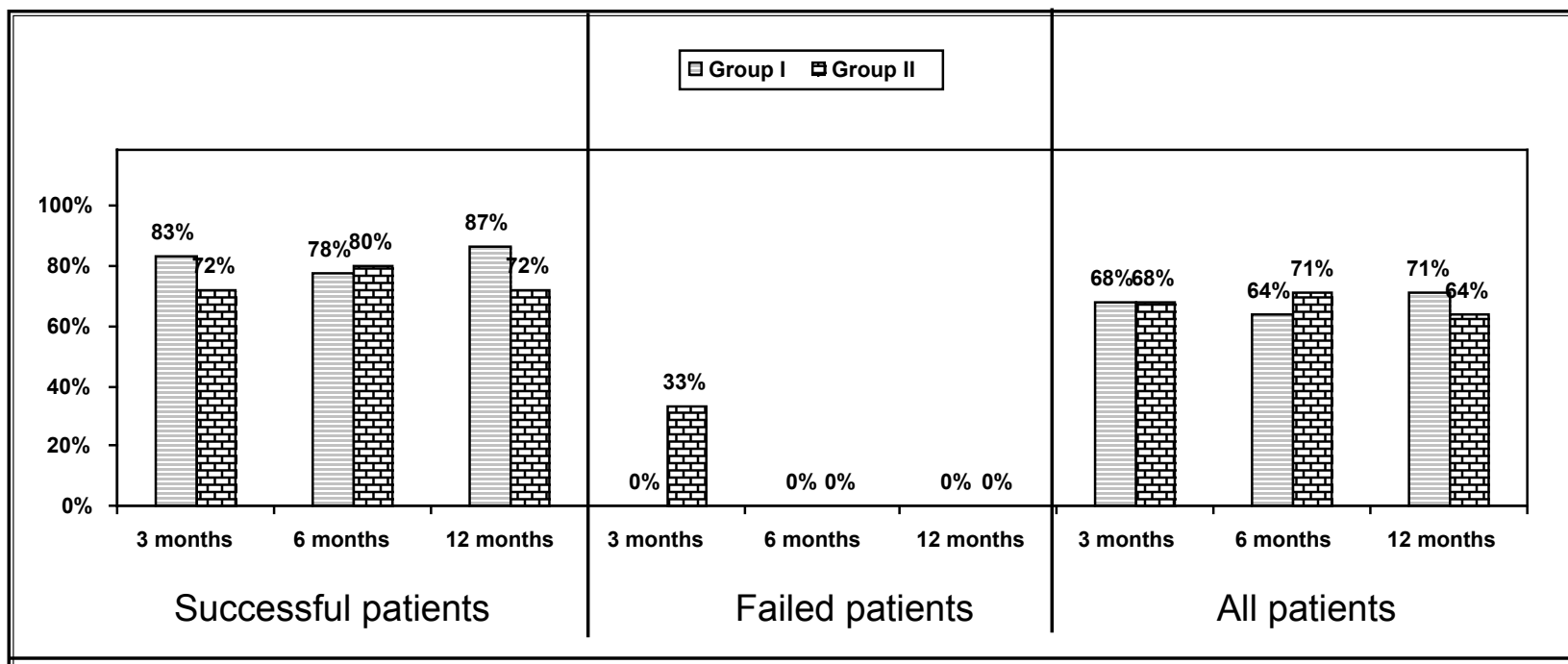

Fig. 2. Illustration of reduction (at least 50\%) in average pain and Neck Disability Index from baseline.

Table 7. Characteristics of changes in weight.

\begin{tabular}{|c|c|c|c|}
\hline \multirow[t]{2}{*}{ Weight (lbs) } & $\begin{array}{c}\text { Group I } \\
(\mathbf{2 8})\end{array}$ & $\begin{array}{c}\text { Group II } \\
(\mathbf{2 8})\end{array}$ & \multirow{2}{*}{$\begin{array}{c}P \\
\text { value }\end{array}$} \\
\hline & Mean \pm SD & Mean \pm SD & \\
\hline Weight at Beginning & $200.0 \pm 50.6$ & $179.2 \pm 39.9$ & 0.093 \\
\hline Weight at One Year & $199.0 \pm 50.8$ & $176.6 \pm 36.2$ & 0.063 \\
\hline Change & $-1.0 \pm 17.0$ & $-2.6 \pm 9.3$ & 0.663 \\
\hline Lost Weight & $50 \%$ & $46 \%$ & \multirow{3}{*}{0.578} \\
\hline No Change & $14 \%$ & $7 \%$ & \\
\hline Gained Weight & $36 \%$ & $47 \%$ & \\
\hline
\end{tabular}

\section{Changes in Weight}

There were no differences in change (gain or loss) in body weight from baseline in both groups (Table 7).

\section{Adverse Events}

Of the 215 cervical epidural procedures performed, there were 2 subarachnoid punctures and 2 intravascular entries. There were no headaches or other complications.

\section{Discussion}

This preliminary report of the one-year followup of a randomized trial of 56 patients with cervical postsurgery syndrome demonstrates significant pain relief $(\geq 50 \%)$ and significant improvement in func- tional status ( $50 \%$ or greater reduction in NDI scores) in $71 \%$ receiving local anesthetic only and $64 \%$ receiving local anesthetic and steroids. The overall average procedures per year was $3.7 \pm 0.9$ in Group I and $4.0 \pm$ 1.1 in Group II, with an average total relief per year of $33.2 \pm 17.4$ weeks in Group I and $37.8 \pm 18.2$ weeks in Group II, for the 52 week period. However, in the successful group total relief per year was $39.6 \pm 11.8$ weeks in Group I and $41.2 \pm 15.8$ weeks in Group II with average relief per procedure of $12.8 \pm 3.1$ weeks in Group I and $15.3 \pm 11.9$ weeks in Group II subsequent to the first 2 procedures.

Despite significant use of epidural injections in the cervical spine, there has been only one systematic review (1), and a Cochrane review of medicinal and injection therapies for mechanical neck disorders (69). Of the randomized evaluations included in the evidence synthesis (34-36), Benyamin et al (1) concluded that all 3 studies showed positive results for short-term relief, whereas 2 were positive for long-term relief; the results of long-term relief were not available for one study (36), defining short-term relief as 6 months, and longterm relief as greater than 6 months. As illustrated in the present study, cervical interlaminar epidural injections of local anesthetic with or without steroids do not provide long-term relief, even though long-term relief can be achieved by appropriate patient evaluation and judicious use of repeat injection therapy. The study illustrates an average relief of 11.8 to 14.8 weeks in the therapeutic phase after 2 initial injections. These re- 
sults are similar to patients with low back pain secondary to postsurgery syndrome treated with caudal epidural injections with or without steroids utilizing the same methodology, but somewhat less effective than cervical epidural injections in patients with or without disc herniation.

Further, this study also provides insight into successful or failed groups based on the first 2 procedures. The patients in the successful group who had good pain relief with the first and second procedures showed average relief from 39.6 to 41.2 weeks out of 52 weeks. The average number of procedures per year was 4 . In contrast, in the failed group, the average relief per procedure was 1.9 to 3.3 weeks, with overall 4.4 to 9.0 weeks of relief in one year.

One of the advantages of this evaluation is its generalizability to interventional pain management settings. This is the first study performed under fluoroscopic visualization in the United States. The results of this study can be applied to individual patients or groups that differ from those controlled in the placebo trials. Pragmatic or practical clinical trials (with an active control) measuring effectiveness are considered more appropriate than explanatory trials measuring efficacy (7-10,18,70-73). Pragmatic trials are best designed to provide the results of treatment benefits produced in routine clinical practice, measuring existence of effect and comparison of 2 treatments in contrast to explanatory trials (placebo control) that measure efficacy and absolute effect size. The present design with active control shows not only the existence of effect, but also compares 2 commonly used therapies (72). This study is also different from other studies since we used repeat cervical interlaminar epidural injections based on the requirement that there be an increase in pain and deterioration in functional status, rather than routinely providing 3 injections or being limited to 3 procedures or limiting them even to only one or 2 procedures. Further, this study also has taken into consideration that the initial 2 procedures do not last for long periods of time. If the initial relief did not last more than one to 3 weeks, then the procedures did not provide long-term relief as was observed in the failed patients.

The study may be criticized or considered as deficient due to the lack of a placebo group and that this is a preliminary analysis $(7-10,18,74)$. However, the issue of a lack of a placebo group is addressed in pragmatic trials with a treatment response that accounts for the total difference between 2 treatments, as well as asso- ciated placebo effects, thus providing internal validity. This preliminary report might resolve to some extent the issue of local anesthetics with or without steroids in managing chronic function-limiting neck pain and upper extremity pain in patients with cervical postsurgery syndrome. The preliminary sample size is appropriate based on recent studies $(67,68)$.

Placebo-controlled neural blockade is not realistic even though it has been misinterpreted $(18,74-76)$. Some have mistakenly reported that any local anesthetic injection which yields similar results as steroids is considered a placebo. However, these interpretations are inaccurate. The evaluations have illustrated sodium chloride solution and dextrose to be active agents. Sodium chloride solution has different effects when injected into either the disc, the facet joint, or paraspinal muscles (77-80).

While the mechanism of action of steroids and local anesthetic has been described (36,39-48,81-85), there is emerging evidence that local anesthetics may be equally as effective as steroids in managing low back and neck pain without disc herniation and also pain of facet joint origin $(37,38,42,48-58)$. It has been reported that multiple pathophysiologic mechanisms involved in chronic pain, including noxious peripheral stimulation, excess nociception resulting in the sensitization of the pain pathways at several neuronal levels, and excess release of neurotransmitters causing complex central responses including hyperalgesia or wind-up (36), result in an increase in nociceptive sensitization of the nervous system $(85,86)$ and phenotype changes which are also considered as part of the neuronal plasticity (8587). Thus, there is evidence for the long-term effect of either local anesthetics or steroids in managing radicular pain. Corticosteroid anti-inflammatory properties have been associated with the inhibition of prostaglandin synthesis and decreases in regional levels or inflammatory mediators such as interleukin-1, tumor necrosis factor, and phospholipase A2 (36,39-48,88-90). The results of this preliminary report show no additional improvement with corticosteroids in managing chronic neck pain with or without upper extremity pain. In addition, corticosteroids are also known to possess direct neurotoxic effects on peripheral nerve tissue unlike local anesthetics (91-93).

In summary, the evidence in this preliminary evaluation of a randomized, controlled, double-blind trial demonstrates that cervical interlaminar epidural injections in patients with previous cervical surgery who have continued pain supports that patients may be 
treated with cervical interlaminar epidural injections with or without steroids.

Multiple complications also have been described with cervical epidural injections, including infection, bleeding, neural trauma, etc. (1,94-99); however, only 2 cases of subarachnoid puncture and intervascular entry were observed without further side effects.

\section{Conclusion}

The assessment of the preliminary results of this randomized, controlled, double-blind trial of cervical interlaminar epidural injections in chronic functionlimiting neck pain and upper extremity pain in cervical postsurgery syndrome demonstrated significant pain relief in over $72 \%$ of patients with improvement in functional status, requiring 4 procedures per year and providing almost 40 weeks of relief during a 52-week period in appropriately selected patients.

\section{Acknowledgements}

The authors wish to thank Sekar Edem for assistance in search of literature, Tom Prigge, MA, for manuscript review, and Tonie M. Hatton and Diane E. Neihoff, transcriptionists, for their assistance in preparation of this manuscript. We would like to thank the editorial board of Pain Physician for review and criticism in improving the manuscript.

\section{References}

1. Benyamin RM, Singh V, Parr AT, Conn A, Diwan S, Abdi S. Systematic review of the effectiveness of cervical epidurals in the management of chronic neck pain. Pain Physician 2009; 12:137-157.

2. Manchikanti L. Singh V, Datta S, Cohen SP, Hirsch JA. Comprehensive review of epidemiology, scope, and impact of spinal pain. Pain Physician 2009; 12:E35E7o.

3. Hogg-Johnson S, van der Velde G, Carroll LJ, Holm LW, Cassidy JD, Guzman J, Côté P, Haldeman S, Ammendolia C, Carragee E, Hurwitz E, Nordin M, Peloso P; Bone and Joint Decade 2000-2010 Task Force on Neck Pain and Its Associated Disorders. The burden and determinants of neck pain in the general population: Results of the Bone and Joint Decade 2000-2010 Task Force on Neck Pain and Its Associated Disorders. Spine (Phila Pa 1976) 2008; 33:S39-S51.

4. Carette $S$, Fehlings MG. Clinical practice. Cervical radiculopathy. $N$ Engl] Med 2005; 353:392-399.

5. Manchikanti L, Pampati V, Boswell MV, Smith HS, Hirsch JA. Analysis of the growth of epidural injections and costs in the Medicare population: A comparative evaluation of 1997, 2002, and 2006 data. Pain Physician 2010; 13:199-212.

6. Manchikanti L, Pampati V, Singh V, Boswell MV, Smith HS, Hirsch JA. Explosive growth of facet joint interventions in the Medicare population in the United States: A comparative evaluation of 1997, 2002, and 2006 data. BMC Health Serv Res 2010; 10:84.

7. Manchikanti L, Datta S, Derby R, Wolfer LR, Benyamin RM, Hirsch JA. A critical review of the American Pain Society clinical practice guidelines for interventional techniques: Part 1. Diagnostic interventions. Pain Physician 2010; 13:E141-E174.

8. Manchikanti L, Datta S, Gupta S, Munglani R, Bryce DA, Ward SP, Benyamin RM, Sharma ML, Helm II S, Fellows B, Hirsch JA. A critical review of the American Pain Society clinical practice guidelines for interventional techniques: Part 2. Therapeutic interventions. Pain Physician 2010; 13:E215-E264.

9. Manchikanti L, Falco FJE, Boswell MV, Hirsch JA. Facts, fallacies, and politics of comparative effectiveness research: Part 1. Basic considerations. Pain Physician 2010; 13:E23-E54.

10. Manchikanti L, Falco FJE, Boswell MV, Hirsch JA. Facts, fallacies, and politics of comparative effectiveness research: Part 2. Implications for interventional pain management. Pain Physician 2010; 13:E55-E79.

11. Manchikanti L, Singh V, Boswell MV. Interventional pain management at crossroads: The perfect storm brewing for a new decade of challenges. Pain Physician 2010; 13:E111-E140.

12. Benyamin RM, Datta S, Falco FJE. A perfect storm in interventional pain management: Regulated, but unbalanced. Pain Physician 2010; 13:109-116.

13. Manchikanti L, Ailinani $\mathrm{H}$, Koyyalagunta D, Datta S, Singh V, Eriator I, Sehgal N Shah RV, Benyamin RM, Vallejo R, Fellows B, Christo PJ. A systematic review of randomized trials of long-term opioid management for chronic non-cancer pain. Pain Physician 2011; 14:91-121.

14. Manchikanti L, Vallejo R, Manchikanti
KN, Benyamin RM, Datta S, Christo PJ. Effectiveness of long-term opioid therapy for chronic non-cancer pain. Pain Physician 2011; 14:E133-E156.

15. Wang MC, Chan L, Maiman DJ, Kreuter W, Deyo RA. Complications and mortality associated with cervical spine surgery for degenerative disease in the United States. Spine (Phila Pa 1976) 2007; 32:342347.

16. Manchikanti L, Singh V, Caraway DL, Benyamin RM, Hirsch JA. Medicare physician payment systems: Impact of 2011 schedule on interventional pain management. Pain Physician 2011; 14:E5-E33.

17. Manchikanti L, Hirsch JA. Medicare physician payment rules for 2011: A primer for the neurointerventionalist. J Neurointervent Surg 2011; 3:399-402.

18. Manchikanti L, Falco FJ, Benyamin RM, Helm $S$ 2nd, Parr AT, Hirsch JA. The impact of comparative effectiveness research on interventional pain management: Evolution from Medicare Modernization Act to Patient Protection and Affordable Care Act and the PatientCentered Outcomes Research Institute. Pain Physician 2011; 14:E249-E282.

19. Manchikanti L, Caraway DL, Parr AT, Fellows B, Hirsch JA. Patient Protection and Affordable Care Act of 2010: Reforming health care reform for the new decade. Pain Physician 2011; 14:E35-E67.

20. Manchikanti L, Parr AT, Singh V, Fellows B. Ambulatory surgery centers and interventional techniques: A look at long-term survival. Pain Physician 2011; 14:E177-E215.

21. Manchikanti L, Fellows B, Ailinani $\mathrm{H}$, Pampati V. Therapeutic use, abuse, and 
nonmedical use of opioids: A ten-year perspective. Pain Physician 2010; 13:401435.

22. Helgeson MD, Albert TJ. Surgery for failed cervical spine surgery. Spine (Phila Pa 1976) 2011 Nov 8. [Epub ahead of print]

23. Patil PG, Turner DA, Pietrobon R. National trends in surgical procedures for degenerative cervical spine disease: 1990-2000. Neurosurgery 2005; 57:753758.

24. Irwin ZN, Hilibrand A, Gustavel $M$, McLain R, Shaffer W, Myers M, Glaser J, Hart RA. Variation in surgical decision making for degenerative spinal disorders. Part II: cervical spine. Spine (Phila $\mathrm{Pa} \mathrm{1976)} \mathrm{2005;} \mathrm{30:2214-2219.}$

25. Greiner-Perth R, Allam $\mathrm{Y}$, El-Saghir H, Röhl F, Franke J, Böhm H. Analysis of reoperations after surgical treatment of degenerative cervical spine disorders: A report on 900 cases. Cen Eur Neurosurg 2009; 70:3-8.

26. Shamji MF, Cook C, Pietrobon R, Tackett S, Brown C, Isaacs RE. Impact of surgical approach on complications and resource utilization of cervical spine fusion: A nationwide perspective to the surgical treatment of diffuse cervical spondylosis. Spine J 2009; 9:31-38.

27. Gok B, Sciubba DM, McLoughlin GS, McGirt M, Ayhan S, Wolinsky JP, Bydon A, Gokaslan ZL, Witham TF. Revision surgery for cervical spondylotic myelopathy: Surgical results and outcome. Neurosurgery 2008; 63:292-298.

28. Bolesta MJ, Rechtine GR II, Chrin AM. Three- and four-level anterior cervical discectomy and fusion with plate fixation: A prospective study. Spine (Phila Pa 1976) 2000; 25:2040-2044.

29. Massie JB, Huang B, Malkmus S, Yaksh TL, Kim CW, Garfin SR, Akeson WH. A preclinical post laminectomy rat model mimics the human post laminectomy syndrome. J Neurosci Methods 2004; 137:283-289.

30. Massie JB, Schimizzi AL, Huang B, Kim CW, Garfin SR, Akeson WH. Topical high molecular weight hyaluronan reduces radicular pain post laminectomy in a rat model. Spine ] 2005; 5:494-502.

31. Harrington JF, Messier AA, Hoffman L, Yu E, Dykhuizen M, Barker K. Physiological and behavioral evidence for focal nociception induced by epidural glutamate infusion in rats. Spine (Phila Pa 1976) 2005; 30:606-612.

32. Haq I, Cruz-Almeida Y, Siqueira EB, No- renberg $M$, Green BA, Levi AD. Postoperative fibrosis after surgical treatment of the porcine spinal cord: A comparison of dural substitutes. Invited submission from the Joint Section Meeting on Disorders of the Spine and Peripheral Nerves, March 2004. J Neurosurg Spine 2005; 2:50-54.

33. Kim KD, Wang JC, Robertson DP, Brodke DS, BenDebba M, Block KM, diZerega GS. Reduction of leg pain and lower-extremity weakness for 1 year with Oxiplex/SP gel following laminectomy, laminotomy, and discectomy. Neurosurg Focus 2004; 17:ECP1.

34. Stav A, Ovadia L, Sternberg A, Kaadan M, Weksler N. Cervical epidural steroid injection for cervicobrachialgia. Acta Anaesthesiol Scand 1993; 37:562-566.

35. Castagnera L, Maurette $P$, Pointillart V, Vital JM, Erny P, Senegas J. Long term results of cervical epidural steroid injection with and without morphine in chronic cervical radicular pain. Pain 1994; 58:239-243.

36. Pasqualucci A, Varrassi G, Braschi A, Peduto VA, Brunelli A, Marinangeli $F$, Gori F, Colò F, Paladini A, Mojoli F. Epidural local anesthetic plus corticosteroid for the treatment of cervical brachial radicular pain: Single injection versus continuous infusion. Clin J Pain 2007; 23:551-557.

37. Manchikanti L, Cash KA, Pampati V, Wargo BW, Malla Y. The effectiveness of fluoroscopic cervical interlaminar epidural injections in managing chronic cervical disc herniation and radiculitis: Preliminary results of a randomized, double-blind, controlled trial. Pain Physician 2010; 13:223-236.

38. Manchikanti L, Cash KA, Pampati V, Wargo BW, Malla Y. Cervical epidural injections in chronic discogenic neck pain without disc herniation or radiculitis: Preliminary results of a randomized, double-blind, controlled trial. Pain Physician 2010; 13:E265-E278.

39. Byrod G, Otani K, Brisby H, Rydevik B, Olmarker K. Methylprednisolone reduces the early vascular permeability increase in spinal nerve roots induced by epidural nucleus pulposus application. J Orthop Res 2000; 18:983-987.

40. Lee HM, Weinstein JN, Meller ST, Hayashi N, Spratt KF, Gebhart GF. The role of steroids and their effects on phospholipase A2: An animal model of radiculopathy. Spine (Phila Pa 1976) 1998; 23:1191-1196.
41. Minamide A, Tamaki T, Hashizume H, Yoshida M, Kawakami M, Hayashi N. Effects of steroids and lipopolysaccharide on spontaneous resorption of herniated intervertebral discs: An experimental study in the rabbit. Spine (Phila Pa 1976) 1998; 23:870-876.

42. Tachihara $H$, Sekiguchi M, Kikuchi $S$, Konno S. Do corticosteroids produce additional benefit in nerve root infiltration for lumbar disc herniation. Spine (Phila Pa 1976) 2008; 33:743-747.

43. Hua SY, Chen YZ. Membrane receptormediated electrophysiological effects of glucocorticoid on mammalian neurons. Endocrinology 1989; 124:687-691.

44. Flower RJ, Blackwell GJ. Anti-inflammatory steroid induced biosynthesis of a phospholipase Az inhibitor which prevents prostaglandin generation. Nature 1979; 278:456-459.

45. Hayashi N, Weinstein JN, Meller ST, Lee HM, Spratt KF, Gebhart GF. The effect of epidural injection of betamethasone or bupivacaine in a rat model of lumbar radiculopathy. Spine (Phila Pa 1976) 1998; 23:877-885.

46. Pasqualucci A. Experimental and clinical studies about the preemptive analgesia with local anesthetics. Possible reasons of the failure. Minerva Anestesiol 1998; 64:445-457.

47. Arner S, Lindblom U, Meyerson BA, Molander $\mathrm{C}$. Prolonged relief of neuralgia after regional anesthetic block. A call for further experimental and systematic clinical studies. Pain 1990; 43:287-297.

48. Sato C, Sakai A, Ikeda Y, Suzuki H, Sakamoto $A$. The prolonged analgesic effect of epidural ropivacaine in a rat model of neuropathic pain. Anesth Analg 2008; 106:313-320.

49. Manchikanti L, Singh V, Falco FJE, Cash KA, Pampati V. Evaluation of lumbar facet joint nerve blocks in managing chronic low back pain: A randomized, doubleblind, controlled trial with a 2-year follow-up. Int J Med Sci 2010; 7:124-135.

50. Manchikanti L, Singh V, Falco FJE, Cash KA, Fellows B. Comparative outcomes of a 2-year follow-up of cervical medial branch blocks in management of chronic neck pain: A randomized, double-blind controlled trial. Pain Physician 2010; 13:437-450.

51. Manchikanti L, Singh V, Falco FJE, Cash KA, Pampati V, Fellows B. Comparative effectiveness of a one-year follow-up of thoracic medial branch blocks in management of chronic thoracic pain: A ran- 
domized, double-blind active controlled trial. Pain Physician 2010; 13:535-548.

52. Manchikanti L, Cash KA, McManus CD, Pampati V, Smith HS. One year results of a randomized, double-blind, active controlled trial of fluoroscopic caudal epidural injections with or without steroids in managing chronic discogenic low back pain without disc herniation or radiculitis. Pain Physician 2011; 14:25-36.

53. Manchikanti L, Singh V, Cash KA, Pampati V, Damron KS, Boswell MV. A randomized, controlled, double-blind trial of fluoroscopic caudal epidural injections in the treatment of lumbar disc herniation and radiculitis. Spine (Phila Pa 1976) 2011; 36:1897-1905.

54. Manchikanti L, Singh V, Cash KA, Pampati $V$, Datta S. Management of pain of post lumbar surgery syndrome: Oneyear results of a randomized, doubleblind, active controlled trial of fluoroscopic caudal epidural injections. Pain Physician 2010; 13:509-521.

55. Manchikanti L, Cash RA, McManus CD Pampati V, Fellows B. Fluoroscopic caudal epidural injections with or without steroids in managing pain of lumbar spinal stenosis: One year results of randomized, double-blind, active-controlled trial. J Spinal Disord 2011; April 5 [Epub ahead of print].

56. Manchikanti L, Singh V, Falco FJE, Cash KA, Pampati V. Evaluation of the effectiveness of lumbar interlaminar epidural injections in managing chronic pain of lumbar disc herniation or radiculitis: A randomized, double-blind, controlled trial. Pain Physician 2010; 13:343-355.

57. Manchikanti L, Cash KA, McManus CD, Pampati V, Benyamin RM. Preliminary results of a randomized, double-blind, controlled trial of fluoroscopic lumbar interlaminar epidural injections in managing chronic lumbar discogenic pain without disc herniation or radiculitis. Pain Physician 2010; 13:E279-E292.

58. Manchikanti L, Cash KA, McManus CD, Pampati V, Benyamin RM. A preliminary report of a randomized double-blind, active controlled trial of fluoroscopic thoracic interlaminar epidural injections in managing chronic thoracic pain. Pain Physician 2010; 13:E357-E369.

59. Manchikanti L, Pampati V, Cash KA. Protocol for evaluation of the comparative effectiveness of percutaneous adhesiolysis and caudal epidural steroid injections in low back and/or lower extremity pain without post surgery syndrome or spinal stenosis. Pain Physician
2010; 13:E91-E110.

6o. Altman DG, Schulz KF, Moher D, Egger M, Davidoff F, Elbourne D, Gøtzsche PC, Lang T; CONSORT GROUP (Consolidated Standards of Reporting Trials). The revised CONSORT statement for reporting randomized trials: Explanation and elaboration. Ann Intern Med 2001; 134:663-694.

61. Cleland JA, Childs JD, Whitman JM. Psychometric properties of the Neck Disability Index and Numeric Pain Rating Scale in patients with mechanical neck pain. Arch Phys Med Rehabil 2008; 89:6974.

62. Pietrobon R, Coeytaux RR, Carey TS, Richardson WJ, DeVellis RF. Standard scales for measurement of functional outcome for cervical pain or dysfunction: A systematic review. Spine (Phila Pa 1976) 2002; 27:515-522.

63. Vernon $\mathrm{H}$, Mior S. The Neck Disability Index: A study of reliability and validity. J Manipulative Physiol Ther 1991; 14:409415.

64. Pereira J, Lawlor P, Vigano A, Dorgan M, Bruera E. Equianalgesic dose ratios for opioids. A critical review and proposals for long-term dosing. J Pain Symptom Manage 2001; 22:672-687. Narcotic analgesic converter, GlobalRPh Inc. www. globalrph.com/narcotic.cgi

65. Browner WS, Newman TB, Cummings SR, Hulley SB. Estimating sample size and power. In: Hulley SB, Cummings SR, Browner WS, Grady D, Hearst N, Newman TB (eds). Designing Clinical Research: An Epidemiologic Approach, 2nd ed. Lippincott, Williams \& Wilkins, Philadelphia, 2001, pp 65-84.

66. Koes BW, Scholten RJ, Mens JMA, Bouter LM. Epidural steroid injections for low back pain and sciatica. An updated systematic review of randomized clinical trials. Pain Digest 1999; 9:241-247.

67. Gharibo CG, Varlotta DO, Rhame EE, Liu EC, Bendo JA, Perloff MD. Interlaminar versus transforaminal epidural steroids for the treatment of subacute lumbar radicular pain: A randomized, blinded, prospective outcome study. Pain Physician 2011; 14:499-511.

68. Iversen T, Solberg TK, Romner B, Wilsgaard T, Twisk J, Anke A, Nygaard O, Hasvold T, Ingebrigtsen T. Effect of caudal epidural steroid or saline injection in chronic lumbar radiculopathy: Multicentre, blinded, randomised controlled trial. BM] 2011; 343:d5278.

69. Peloso PMJ, Gross A, Haines T, Trinh
K, Goldsmith $\mathrm{CH}$, Burnie S); Cervical Overview Group. Medicinal and injection therapies for mechanical neck disorders. Cochrane Database Syst Rev 2007; 3:CDooo319.

70. Tunis SR, Stryer DB, Clancy CM. Practical clinical trials. Increasing the value of clinical research for decision making in clinical and health policy. JAMA 2003; 290:1624-1632.

71. Roland $M$, Torgerson $D J$. What are pragmatic trials? $B M]$ 1998; 316:285.

72. International Conference on Harmonisation of Technical Requirements for Registration of Pharmaceuticals for Human Use. ICH Harmonised Tripartite Guideline. Choice of Control Group and Related Issues in Clinical Trials E1o. July 20, 2000. http://private.ich.org/LOB/ media/MEDIA486.pdf

73. Hotopf M, Churchill R, Lewis G. Pragmatic randomized controlled trials in psychiatry. Br J Psychiatry 1999; 175:217223.

74. Manchikanti L, Giordano J, Fellows B, Hirsch JA. Placebo and nocebo in interventional pain management: $A$ friend or a foe - or simply foes? Pain Physician 2011; 14:E157-E175.

75. Manchikanti L, Singh V, Falco FJE. In response to Smuck M, Levin JH. RE: Manchikanti L, Singh V, Falco FJE, Cash KA, Fellows B. Cervical medial branch blocks for chronic cervical facet joint pain: A randomized double-blind, controlled trial with one-year follow-up. Spine (Phila Pa 1976) 2009; 34:1116-1117.

76. Chou R, Huffman L. Guideline for the Evaluation and Management of Low Back Pain: Evidence Review. American Pain Society, Glenview, IL, 2009.

www.ampainsoc.org/pub/pdf/LBPEvidRev.pdf

77. Pham Dang C, Lelong A, Guilley J, Nguyen JM, Volteau C, Venet G, Perrier C, Lejus C, Blanloeil Y. Effect on neurostimulation of injectates used for perineural space expansion before placement of a stimulating catheter: Normal saline versus dextrose $5 \%$ in water. Reg Anesth Pain Med 2009; 34:398-403.

78. Tsui BC, Kropelin B, Ganapathy S, Finucane B. Dextrose $5 \%$ in water: Fluid medium maintaining electrical stimulation of peripheral nerve during stimulating catheter placement. Acta Anaesthesiol Scand 2005; 49:1562-1565.

79. Indahl A, Kaigle AM, Reikeräs O, Holm $\mathrm{SH}$. Interaction between the porcine lumbar intervertebral disc, zygapophysi- 
al joints, and paraspinal muscles. Spine (Phila Pa 1976) 1997; 22:2834-2840.

8o. Indahl A, Kaigle A, Reikerås O, Holm S. Electromyographic response of the porcine multifidus musculature after nerve stimulation. Spine (Phila Pa 1976) 1995; 20:2652-2658.

81. Mao J, Chen LL. Systemic lidocaine for neuropathic pain relief. Pain 2000; 87:717.

82. Ferrante FM, Paggioli J, Cherukuri S, Arthru GR. The analgesic response to intravenous lidocaine in the treatment of neuropathic pain. Anesth Analg 1996; 82:91-97.

83. Lavoie PA, Khazen T, Filion PR. Mechanisms of the inhibition of fast axonal transport by local anesthetics. Neuropharmacology 1989; 28:175-181.

84. Bisby MA. Inhibition of axonal transport in nerves chronically treated with local anesthetics. Exp Neurol 1975; 47:481-489.

85. Kawakami M, Weinstein JN, Chatani K, Spratt KF, Meller ST, Gebhart GF. Experimental lumbar radiculopathy. Behavioral and histologic changes in a model of radicular pain after spinal nerve root irritation with chromic gut ligatures in the rat. Spine (Phila Pa 1976) 1994; 19:1795-1802.

86. Decosterd I, Woolf CJ. Spared nerve injury: An animal model of persistent peripheral neuropathic pain. Pain 2000; 87:149-158.

87. Pennypacker KR, Hong JS, McMillian MK. Implications of prolonged expression of Fos-related antigens. Trends
Pharmacol Sci 1995; 16:317-321.

88. Norimoto $M$, Ohtori $S$, Yamashita $M$, Inoue G, Yamauchi K, Koshi T, Suzuki $M$, Orita S, Eguchi Y, Sugiura A, Ochiai N, Takaso M, Takahashi K. Direct application of the TNF-alpha inhibitor, etanercept, does not affect CGRP expression and phenotypic change of DRG neurons following application of nucleus pulposus onto injured sciatic nerves in rats. Spine (Phila Pa 1976) 2008; 33:2403-2408.

89. Genevay S, Finckh A, Payer M, Mezin F, Tessitore E, Gabay C, Guerne PA. Elevated levels of tumor necrosis factor-alpha in periradicular fat tissue in patients with radiculopathy from herniated disc. Spine (Phila Pa 1976) 2008; 33:2041-2046.

90. Yamashita M, Ohtori S, Koshi T, Inoue G, Yamauchi K, Suzuki M, Takahashi K. Tumor necrosis factor-alpha in the nucleus pulposus mediates radicular pain, but not increase of inflammatory peptide, associated with nerve damage in mice. Spine (Phila Pa 1976) 2008; 33:18361842.

91. Johansson A, Hao J, Sjolund B. Local corticosteroid application blocks transmission in normal nociceptive C-fibres. Acta Anaesthesiol Scand 1990; 34:335-338.

92. Mackinnon SE, Hudson AR, Gentili F, Kline DG, Hunter D. Peripheral nerve injection injury with steroid agents. Plast Reconstr Surg 1982; 69:482-489.

93. Shishido $H$, Kikuchi $S$, Heckman $H$, Myers RR. Dexamethasone decreases blood flow in normal nerves and dorsal root ganglia. Spine (Phila Pa 1976) 2002; 27:581-586.

94. Manchikanti L, Malla Y, Wargo BW, Cash KA, McManus CD, Damron KS, Jackson SD, Pampati V, Fellows B. A prospective evaluation of bleeding risk of interventional techniques in chronic pain. Pain Physician 2011; 14:317-329.

95. Manchikanti L, Malla Y, Wargo BW, Fellows B. Infection control practices (safe injection and medication vial utilization) for interventional techniques: Are they based on relative risk management or evidence? Pain Physician 2011; 14:425434.

96. Gupta R, Shah M, Reese CM. Steroid induced spinal epidural lipomatosis--case report and review of the literature. $\mathrm{W} \mathrm{V}$ Med J 2011; 107:20-22.

97. Shanthanna H, Park J. Acute epidural haematoma following epidural steroid injection in a patient with spinal stenosis. Anaesthesia 2011; 66:837-839.

98. Botwin KP, Castellanos R, Rao S, Hanna AF, Torres-Ramos FM, Gruber RD, Bouchlas CG, Fuoco GS. Complications of fluoroscopically guided interlaminar cervical epidural injections. Arch Phys Med Rehabil 2003; 84:627-633.

99. Manchikanti L, Singh V. Corticosteroids. In: Manchikanti L, Christo PJ, Trescot AM, Falco FJE (eds). Foundations of Pain Medicine and Interventional Pain Management: A Comprehensive Review. ASIPP Publishing, Paducah, KY, 2011, pp 589606. 
